\title{
PELATIHAN PENYUSUNAN PERANGKAT PEMBELAJARAN BERPENDEKATAN SAINTIFIK TERINTEGRASI NILAI KARAKTER BAGI GURU SEKOLAH DASAR
}

\author{
Setyo Eko Atmojo ${ }^{1}$, Beny Dwi Lukitoaji ${ }^{2}$ \\ ${ }^{1,2}$ Program Studi PGSD, Fakultas Keguruan dan Ilmu Pendidikan, \\ Universitas PGRI Yogyakarta \\ Email: setyoekoatmojo@yahoo.co.id
}

\begin{abstract}
The purpose of this activity is to overcome the difficulties of teachers in planning and implementing learning with scientific approach and character value. The method of this activity is in the form of training, then the participants are guided to apply the training results in the process of developing learning tools with scientific approach integrated character value. This training is held 8 times, it is intended that the participants are able to develop and implement scientifically-oriented learning tools that integrate character values correctly. The training results show the average pretest score of 45.72. The score indicates that the participants' knowledge of the scientific approach and the value of the character are still low and the need for training in the preparation of learning tools with a scientific approach that integrates the character values. The average postes result is 78,54. While the average percentage increase in the score from pretest to postes of $32.81 \%$. It shows that the increase of score from pretes to postes has fulfilled the training target that is $>25 \%$. The average of the result of the assessment of learning device product of scientific approach and integrated character value equal to 76,18 which have fulfilled the training target that is $>70$.
\end{abstract}

Keywords: learning tool, scientific approach, character value

\begin{abstract}
Abstrak. Tujuan kegiatan ini adalah mengatasi kesulitan guru dalam merencanakan dan mengimplementasikan pembelajaran dengan pendekatan saintifik dan nilai karakter. Metode kegiatan ini adalah berupa pelatihan, selanjutnya peserta dibimbing untuk menerapkan hasil pelatihan dalam proses menyusun perangkat pembelajaran berpendekatan saintifik terintegrasi nilai karakter. Pelatihan ini dilaksanakan sebanyak 8 kali, hal ini dimaksudkan agar peserta mampu menyusun dan mengimplementasikan perangkat pembelajaran berpendekatan saintifik terintegrasi nilai karakter dengan benar. Hasil pelatihan menunjukkan rata-rata skor pretes sebesar 45,72. Skor tersebut menunjukkan bahwa pngetahuan peserta tentang pendekatan saintifik dan nilai nilai karakter masih rendah dan perlu adanya pelatihan penyusunan perangkat pembelajaran dengan pendekatan saintifik yang mengintegrasikan nilai karakter. Hasil rata-rata postes yaitu sebesar 78,54. Sedangkan rata rata persentase peningkatan skor dari pretes ke postes sebesar 32,81\%. Hal tersebut menunjukkan bahwa peningkatan skor dari pretes ke postes sudah memenuhi target pelatihan yaitu $>25 \%$. Rata rata hasil penilaian produk perangkat pembelajaran berpendekatan saintifik dan terintegrasi nilai karakter sebesar sebesar 76,18 yang sudah memenuhi target pelatihan yaitu $>70$.
\end{abstract}

Kata kunci : perangkat pembelajaran, pendekatan saintifik, nilai karakter

\section{PENDAHULUAN}

Perubahan kurikulum membawa dampak di berbagai sektor pendidikan. Perubahan paling masif dirasakan oleh guru sebagai ujung tobak kegiatan pembelajaran di sekolah. Dalam kurikulum edisi terbaru ini seorang guru dituntut untuk dapat merubah mekanisme pembelajaran yang selama ini dilakukan. Pada kurikulum edisi terbaru in menuntut guru berperan sebagai fasilitator dan siswa lebih aktif selama pembelajaran. Fasilitator disini harus dapat merangsang siswa untuk mengikuti kegiatan pembelajaran secara utuh melalui pendekatan saintifik. Pendekatan saintifik ini biasanya digunkan untuk pembelajaran materi materi Ilmu Pengetahuan Alam (IPA), sebagian guru IPA mungkin sudah tidak asing lagi dengan pendekatan ini. Akan tetpi penerapan pendekatan saintifik ini tetap menajdi sesuatu yang baru dan menimbulkan masalah luar biasa bagi gur sekolah dasar.

Implementasi pendekatan saintifik ini wajib dilakukan oleh guru pada seluruh tema pembelajaran yang diajarkan pada setiap jenjang di sekolah dasar. Penerapan pendekatan saintifik bertujuan untuk pemahaman kepada peserta didik dalam mengenal, memahami berbagai materi 
informasi bisa berasal dari mana saja, kapan saja, tidak bergantung pada informasi searah dari guru (Setiyaningsih, W., Maimunah, M., \& Siregar, S. N. 2018, Suastika, I. K. 2018). Akan tetapi sebagian besar guru disekolah dasar mengalami kesulitan untuk mengimplementasikan pendekatan ini mulai dari perencanaan pembelajaran, melaksanakan pembelajaran di kelas hingga sistem penilaian yang harus dilakukan. Hal tersebut dirasakan oleh guru di berbagai wilayah terutama sekolah di wilayah pinggiran. Salah satu sekolah yang mengalami kesulitan dalam merencanakan dan mengimplementasikan pembelajaran dengan pendekatan saintifik adalah Sekolah Dasar Negeri IV Ngraho yang terletak di Kecamatan Kedungtuban Kabupaten Blora Jawa Tengah. Sebagian besar guru disekolah ini merasa kesulitan untuk memenuhi tuntutan tersebut.

Setali tiga uang dengan implementasi pendekatan saintifik guru di SD Negeri IV Ngraho ini juga kesulitan dalam merancang, mengitegrasikan dan mengimplemantasikan nilai karakter dalam kegiatan pembelajaran di kelas. Hal ini menjadi sebuah masalah baru dalam dunia pendidikan, terutama menyiapkan perangkat pembelajaran yang dapat mendidik siswa menjadi anak-anak yang memiliki kepribadian utuh yaitu anak-anak yang memiliki karakter. Karakter adalah perilaku yang tampak dalam kehidupan sehari-hari baik dalam bersikap maupun dalam bertindak (Zuchdi, D. (2010). Implementasi nilai karakter ini pentig dan harus diterapkan dalam kegiatan pembelajaran sebagai salah satu amanat undang undang. Kegiatan pembelajaran di Sekolah dasar harus lebih banyak membekali siswa dengan nilai nilai karakter di banding dengan pada jenjang pendidikan menengah (Adisusilo, Sutarjo. J.R. 2011). Dalam rangka mewujudkan hal tersebut maka diperlukan sebuah perangkat pembelajaran yang didalamnya mengintegrasikan nilai nilai karakter.

Berdasarkan dua masalah besar tersebut maka diperlukan sebuah kegiatan yang dirancang secara khusus untuk melatih guru dalam menyusun perangkat pembelajaran Berpendekatan Saintifik Terintegrasi Nilai Nilai Karakter. Salah satu cara alternatif untuk meningkatkan kemampuan guru dalam menyusun perangkat pembelajaran berpendekatan saintifik terintegrasi nilai nilai karakter adalah melalui kegiatan pelatihan. Permasalahan yang dihadapi mitra dalam hal ini adalah guru guru di Negeri IV Ngraho ini yaitu kurangnya kemampuan guru dalam merancang, mengimplementasikan, dan mengevaluasi pembelajran yang menggunakan pendekatan saintifik dan mengintegrasikan nilai nilai karakter. Sehingga guru sangat membutuhkan suatu kegiatan (pelatihan) penyusunan perangkat pembelajaran berpendekatan saintifik terintegrasi nilai nilai karakter. Solusi yang dapat ditawarkan untuk mengatasi permasalahan mitra berkaitan dengan kesulitan dalam merancang, mengimplementasikan, dan mengevaluasi pembelajran yang menggunakan pendekatan saintifik dan mengintegrasikan nilai nilai karakter adalah melalui kegiatan pelatihan. Kegiatan pelatihan ini berupa jasa pemberian informasi tentang teknik dan cara merancang, mengimplementasikan, dan mengevaluasi pembelajaran yang menggunakan pendekatan saintifik dan mengintegrasikan nilai nilai karakter. Luaran yang ditargetkan dari hasil pelatihan ini adalah berupa peningkatan pemahaman dari guru setelah mengikuti pelatihan terkait dengan pendekatan saintifik dan nilai nilai karakter dalam kegiatan pembelajaran. Selain pemahaman kegiatan ini diharapkan juga menghasilkan produk, yaitu perangkat pembelajaran yang menggunakan pendekatan saintifik dan mengintegrasikan nilai nilai karakter dari guru yang mengikuti pelatihan.

\section{METODE PELAKSANAAN}

Kegiatan yang dilaksanakan adalah berupa pelatihan pembuatan perangkat pembelajaran berpendekatan saintifik terintegrasi nilai nilai karakter bagi guru sekolah dasar. Metode kegiatan ini berupa pelatihan kepada para guru di SD Negeri IV Ngraho. Setelah diberi pelatihan,selanjutnya mereka dibimbing untuk menerapkan hasil pelatihan dalam rangka meningkatkan kemampuan guru dalam menyusun dan mengimplementasikan perangkat pembelajaran berpendekatan saintifik terintegrasi nilai nilai karakter. Pelatihan dilaksanakan sebanyak 8 kali, hal ini dimaksudkan agar peserta tidak hanya sekedar memahami materi yang disampaikan namun juga mampu menyusun dan mengimplemnetasikan perangkat pembelajaran berpendekatan saintifik terintegrasi nilai nilai karakter secara baik dan benar. Sasaran kegiatan ini adalah seluruh guru di SD Negeri IV Ngraho Kedungtuban Blora Jawa Tengah yang memiliki kesulitan dalam menyusun perangkat pembelajaran berpendekatan saintifik terintegrasi 
nilai nilai karakter. Uraian kegiatan pelatihan ini terdiri dari delapan tahapan kegiatan seperti pada
Gambar 1.

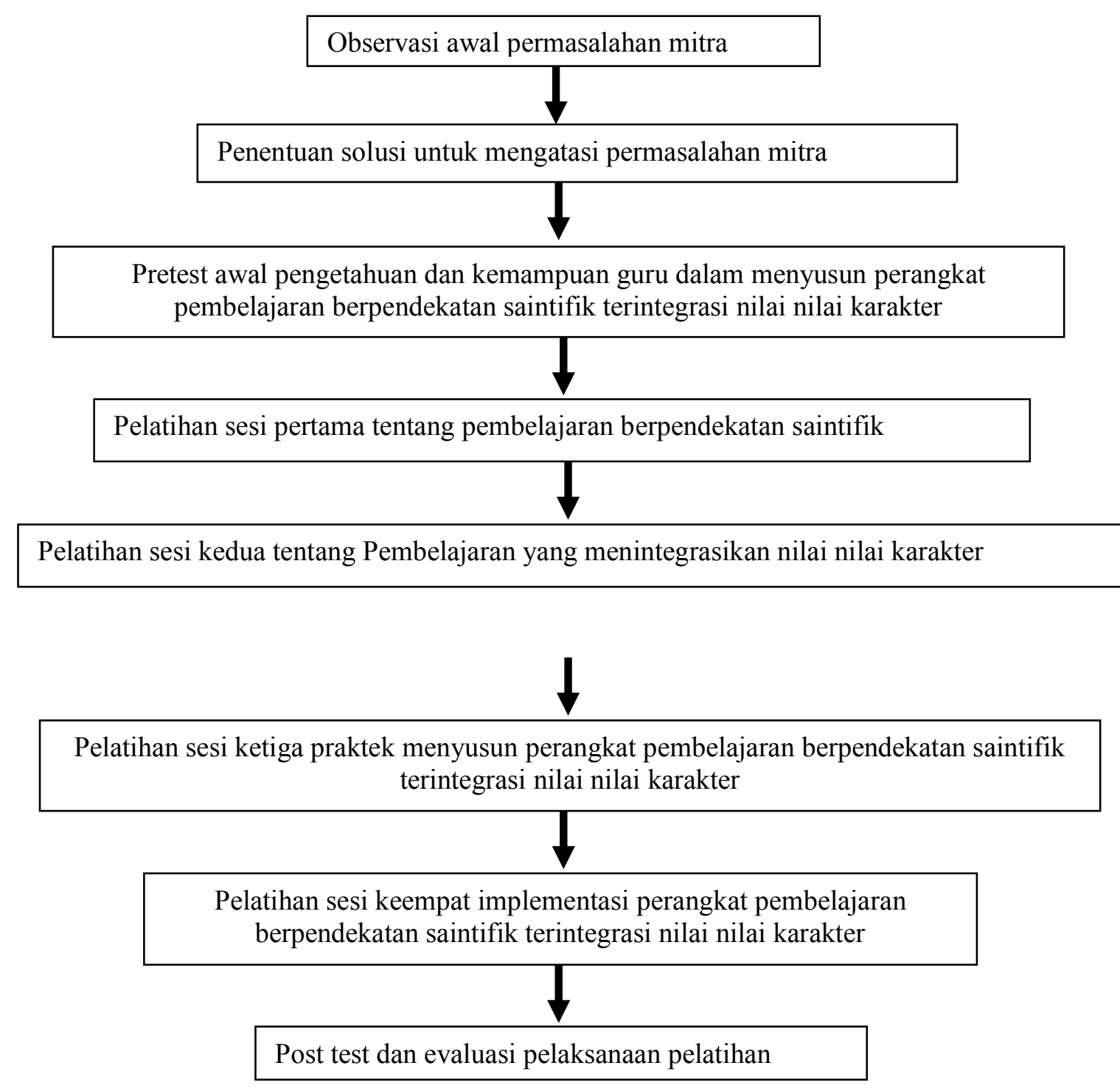

\section{Gambar 1. Tahapan Kegiatan Pengabdian}

\section{HASIL DAN PEMBAHASAN}

Kegiatan pengabdian ini berupa pelatihan kepada guru sekolah dasar tentnag penyususnan perangkat pembelajaran berpendekatan saintifik dan terintgrasi nilai nilai karakter. Kegiatan pelatiahan ini dilakukan sebanyak empat kali kegiatan pengabdian dimana setiap kegiatan terdiri dari dua kali pertemuan sehingga total menjadi sebanyak delapan kali pertemuan pada bulan Februari - Maret 2018. Dengan rangkaian kegiatan sebagai berikut : 1) Minggu ke 1 dan 2 Februari 2018 kegiatan penyampaian materi tentang penyusunan perangkat pembelajaran berpendekatan saintifik terintegrasi nilai nilai karakter, 2) Minggu ke 3 dan 4 Februari 2018 tugas mandiri menyusun perangkat pembelajaran berpendekatan saintifik terintegrasi nilai nilai karakter, 3) Minggu ke 1 dan 2 Maret 2018 kegiatan review dan perbaikan perangkat pembelajaran berpendekatan saintifik terintegrasi nilai nilai karakter dan 4) Minggu ke 3 dan 4 Maret 2018 implementasi rancangan perangkat pembelajaran berpendekatan saintifik terintegrasi nilai nilai karakter yang telah disusun peserta.

Kegiatan pelatihan pertama yaitu pelatihan tentang cara penyusunan perangkat pembelajaran 
berpendekatan saintifik. Kegiatan ini berisi tentang pengertian pembelajaran saintifik, ciri ciri pembelajaran saintifik, dan langkah pembelajaran saintifik. Dalam pengertian pendekatan saintifik ada beberapa langkahlangkah. Proses pembelajaran terdiri atas lima kegiatan pengalaman belajar pokok yaitu: Mengamati, Menanya, Mengumpulkan Informasi / Eksperimen, mengasosiasikan / Mengolah Informasi, dan Mengkomunikasikan.. Pendekatan saintifik dimaksudkan memberikan pemahaman

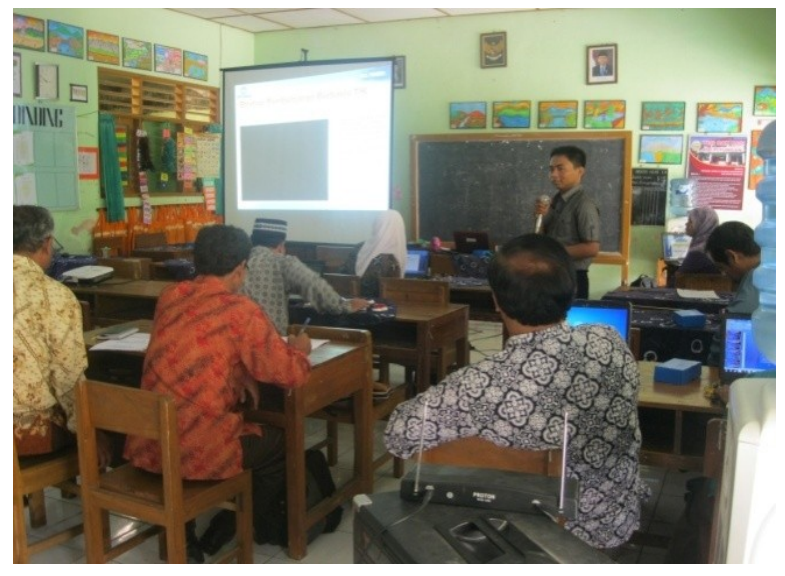

Gambar 2. Pelatihan Pembelajaran Saintifik

Kegiatan pelatihan kedua yaitu pelatihan tentang penyusunan perangkat pembelajaran yang mengintgrasikan nilai karakter. Suasana kegiatan pelatihan sesi kedua ini dapat terlihat pada Gambar 3. Kegiatan ini bertujuan untuk memberikan pengetahuan tentang pentingnya nilai nilai karakter untuk diintegrasikan dalam kegiatan pembelajaran di sekolah dasar. Kata value, yang kemudian diterjemahkan ke dalam bahasa Indonesia menjadi nilai, berasal dari bahasa Latin valere atau Bahasa Prancis Kuno valoir. Menurut Khusniati, M. (2012) nilai adalah rujukan dan keyakinan dalam menentukan pilihan. Nilai sebagai hal yang abstrak, yang harganya mensifati dan disifatkan pada sesuatu hal dan ciri-cirinya dapat dilihat dari tingkah laku, memiliki kaitan dengan istilah fakta, tindakan, norma, moral, cita-cita, keyakinan, dan kebutuhan. Kurniawati, W., \& Atmojo, S. E. (2017) menyatakan bahwa pendidikan karakter pada intinya bertujuan membentuk bangsa yang tangguh, kompetitif, berakhlak mulia, bermoral, bertoleran, bergotong royong, berjiwa patriotik, berkembang dinamis, berorientasi ilmu pengetahuan dan teknologi yang semuanya dijiwai oleh iman dan takwa kepada Tuhan Yang Maha Esa berdasarkan Pancasila. Dalam kepada peserta didik dalam mengenal, memahami berbagai materi menggunakan pendekatan ilmiah, bahwa informasi bisa berasal dari mana saja, kapan saja, tidak bergantung pada infromasi searah guru (Rahmita, Y. G. 2013). Oleh karena itu kondisi pembelajaran yang diarahkan untuk mendorong peserta didik dalam mencari tahu dari berbagai sumber melalui observasi dan bukan hanya diberi tahu. Suasana kegiatan pelatihan sesi pertama ini dapat dilihat pada Gambar 2.

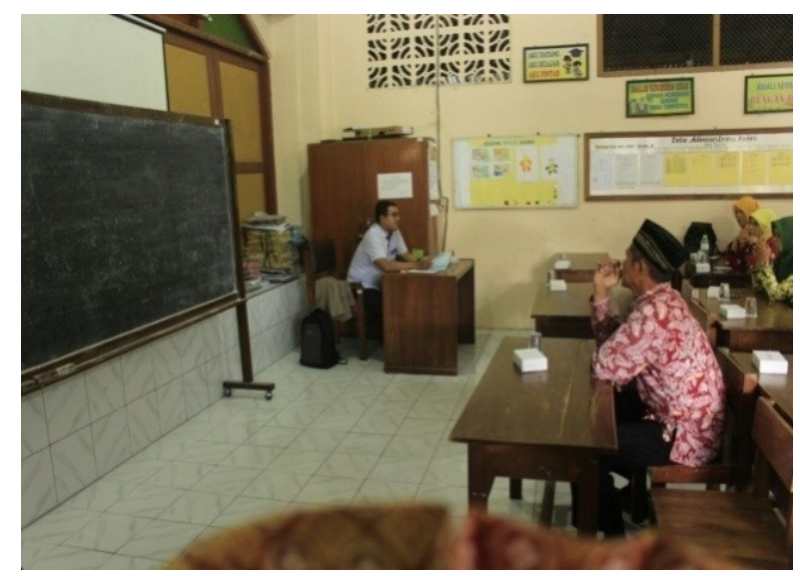

\section{Gambar 3. Pelatihan Pembelajaran Terintegrasi Nilai Karakter}

publikasi pusat kurikulum tersebut dinyatakan bahwa pendidikan karakter berfungsi a) Mengembangkan potensi dasar agar berhati baik, dan berperilaku baik; b) Memperkuat dan membangun perilaku bangsa yang multikultural; c) Meningkatkan peradaban bangsa yang kompetitif dalam pergaulan dunia.

Pelatihan ketiga ini berupa kegiatan penyusunan perangkat pembelajaran berpendekatan saintifik yang menintegrasikan nilai nilai karakter. Pada kegiatan ini masing masing perserta pelatihan menyusun satu buah rencana pelaksanaan pembelajaran berpendekatan saintifik yang berdurasi kurang lebih dua puluh menit untuk selanjutnya diimplementasikan dalamm kegiatan pembelajaran secara mikro. Kegiatan penyusunan perangkat pembelajaran ini didampingi oleh narasumber dalam hal ini adalah tim dosen pengabdi dari prodi PGSD Universitas PGRI Yogyakrta. Kegiatan penyusunan perangkat pembelajaran ini berlangsung sebanyak dua kali pertemuan. Jika dalam dua pertemuan ini perangkat pembelajaran masih ada yang belum selesai maka peserta dapat menyelesaikannya secara mandiri di rumah masing masing. 
Pelatihan keempat ini merupakan lanjutan dari pelatihan ketiga. Dimana pada pelatihan terakhir ini peserta pelatihan mempraktikan perangkat pembelajaran berpendekatan saintifik terintgrasi nilai nilai karakter secara mikro. Kegiatan ini bertujuan untuk mengetahui sejauh mana hasil pelatihan dapat diterapkan dalam rencana pembelajaran yang disusun. Selain itu kegiatan ini juga bertujuan untuk mengetahui kesiapan peserta

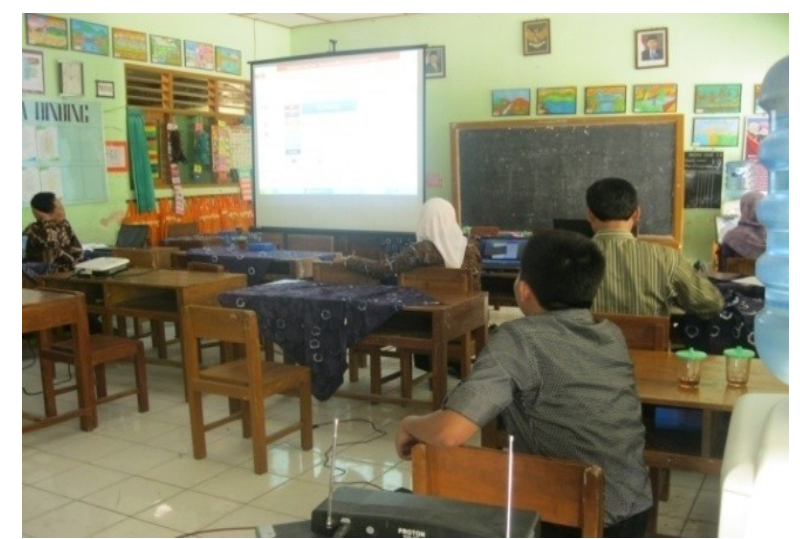

Gambar 4. Praktik Pembelajaran Mikro

Luaran yang dicapai dari hasil pelatihan ini adalah berupa peningkatan pengetahuan dan pemahaman guru stelah mengikuti pelatihan terkait dengan pendekatan saintifik dan nilai nilai karakter dalam kegiatan pembelajaran. Pengetahuan guru tentang pendekatan saintifik dalam mengimplementasikan pembelajaran berpendektan saintifik terintegasi nilai nilai karakter. Dalam kegiatan ini masing masing peserta dan narasumber dapat memberikan saran dan masukkan terkait perangkat pembelajaran dan pelaksanaan pembelaajran secara mikro. Suasana kegiatan pembelajaran berpendekatan saintifik secara mikro dapat dilihat pada Gambar 4 dan 5.

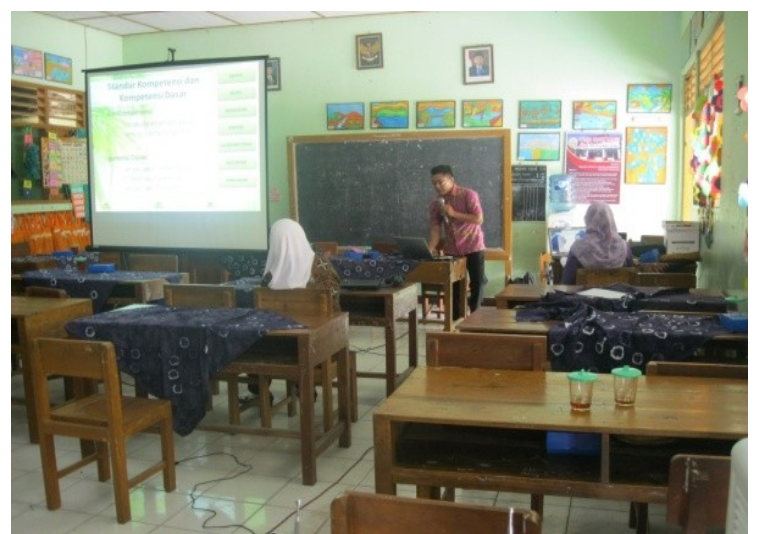

Gambar 5. Praktik Pembelajaran Mikro

dan pembelajaran yang mengintegrasikan nilai karakter dilihat berdasarkan hasil pretest dan postest yang dilakukan sebelum dan setelah pelatihan. Skor hasil pretest dan posttest peserta pelatihan dapat dilihat padaTabel 1 .

Tabel 1. Skor Pretest Dan Posttest Peserta Pelatihan

\begin{tabular}{llccc}
\hline No & \multicolumn{1}{c}{ Peserta } & Skor Pretest & Skor Posttest & Persentase Peningkatan \\
\hline 1 & Sri Subekti, S.Pd & 42 & 80 & 38 \\
2 & Hasyim, S.Pd & 45 & 78 & 33 \\
3 & Sutrisno, S.Pd & 50 & 82 & 32 \\
4 & Marsini, S.Pd & 35 & 71 & 36 \\
5 & Suyatini, S.Pd & 47 & 82 & 35 \\
6 & Nanik Maharani, S.Pd & 52 & 84 & 32 \\
7 & Tri Yanawati, A.Ma.Pd & 48 & 73 & 31 \\
8 & Prihatiningsih, S.Pd.SD & 54 & 86 & 34 \\
9 & Suyanto, S.Pd.SD & 40 & 68 & 30 \\
10 & Siti Rukayah, S.Pd.SD & 48 & 71 & 32 \\
11 & Heri Purnomo, S.Pd.SD & 46 & 70 & 28 \\
\hline & Jumlah Skor & 503 & 864 & 361 \\
\hline & Rata rata & 45,72727 & 78,54545 & 32,81818 \\
\hline
\end{tabular}

Berdasarkan pada Tabel 1 diketahui bahwa rata rata skor pretest sebesar 45,72 dari skala 100 . Skor tersebut menunjukkan bahwa pengetahuan dan pemahaman tentang peserta pelatihan dalam menyusun perangkat pembelajaran berpendekatan saintifik terintegrasi nilai karakter masih rendah dan perlu adanya kegiatan pelatihan penyusunan perangkat pembelajaran tersebut. Setelah menerima pelatihan sebnayak delapan kali pertemuan termasuk didalmnya klinis penyusunan perangkat dan implementasi rencana pembelajaran secara mikro peserta 
pelatihan menghasilkan perangkat pembelajaran berpendekatan saintifik terintegrasi nilai karakter sesui dengan kelas yang mereka ajar. Pada akhir kegiatan pelatihan dilakukan posttest untuk mengathui sejauh mana pengusaaan pengetahuan peserta pelatihan tentang pembelajaran berpendekatan saintifik yang terintegrasi nilai karakter. Rata rata skor hasil post test adalah sebesar 78,54. Pada Tabel .1 juga diketahui besarnya rata rata peningkatan pengetahuan peserta setelah pelatihan adalah sebesar $32,81 \%$ yang menunjukkan bahwa peningkatan dari pretest ke postest telah memenuhi target dari pelatihan ini. Selain peningkatan pengetahuan peserta pelatihan ini juga menghasilkan sebuah produk perangkat pembelajaran berpendekatan saintifik terintegrasi nilai karakter. Hasil penilaian terhadap perangkat pembelajaran yang dihasilkan dapat dilihat pda Tabel 2.

Tabel 2. Skor Penilaian Perangkat Pembelajaran

\begin{tabular}{clc}
\hline No & \multicolumn{1}{c}{ Nama } & Skor \\
\hline 1 & Sri Subekti, S.Pd & 72 \\
2 & Hasyim, S.Pd & 78 \\
3 & Sutrisno, S.Pd & 82 \\
4 & Marsini, S.Pd & 80 \\
5 & Suyatini, S.Pd & 75 \\
6 & Nanik Maharani, S.Pd & 76 \\
7 & Tri Yanawati, A.Ma.Pd & 70 \\
8 & Prihatiningsih, S.Pd.SD & 81 \\
9 & Suyanto, S.Pd.SD & 80 \\
10 & Siti Rukayah, S.Pd.SD & 73 \\
11 & Heri Purnomo, S.Pd.SD & 71 \\
\hline & Jumlah Skor & 838 \\
\hline & Rata rata & 76,18182 \\
\hline
\end{tabular}

Berdasarkan Tabel 2 dapat diketahui bahwa seluruh peserta pelatihan telah mampu menyusun perangkat pembelajaran berbendekatan saintifik terintegrasi nilai karakter. Berdasarkan Tabel 7 dapat diketahui juga bahwa skor rata rata penilaian terhadap perangkat pembelajaran adalah sebesar 76,18 yang berarti telah memenuhi indikator keberhasilan pelatihan. Skor rata rata hasil penilaian terhadap perangkat pembelajaran yang telah di buat oleh peserta pelatihan lebih dari skor minimal keberhasilan pelatihan yaitu 70 . Perangkat pembelajaran berpendekatan sainstifik menunutt guru berubah total dalam mengajar. Guru harus dapat merancang berbagai aktivitas yang memungkinkan dan mendorong siswa untuk mencari dan menemukan sendiri, masalah, prinsip, aturan, hukum yang menjadi inti dari kegiatan pembelajaran (Marjan, J., Arnyana, I. B. P., Si, M., Setiawan, I. G. A. N., \& Si, M. 2014; Ricahyono, S., \& Arifin, S. 2016). Materi dan inti kegiatan pembelajaran tidak lagi disampaiakan oleh guru dengan ceramah akan tetapi siswa menemukan sendiri. Dalam kaitan inilah pendekatan saintifik disebut pendekatan yang beorientasi siswa. Dalam pendekatan saintifik ini siswa didorong dan diberi kesempatan menjadi siswa yang aktif dan terlibat secara penuh sebagai pencari kebenaran.

\section{SIMPULAN DAN SARAN}

Hasil kegiatan pelatihan penyusunan perangkat pembelajaran berpendekatan saintifik terintegrasi nilai karakter menunjukkan bahwa telah terjadi peningkatan rata rata skor pengetahuan peserta dari pretest ke postest sebesar 32,81\%. Peningkatan skor tersebut telah memenuhi kriteria minimal keberhasilan kegiatan yaitu peningkatan pengetahuan yang lebih dari $25 \%$. Skor rata rata penilaian terhadap produk pelatihan berupa perangkat pembelajaran berpendekatan saintifik terintegras nilai karakter sebesar 76,18. Rata rata penilaian tersebut juga juga telah mencapai kriteria keberhasilan pelatihan yaitu lebih dari 70. Saran untuk pelatiahan selanjutnya yaitu kegiatan dapat dilakukan lebih intensif dengan durasi waktu yang lebih panjang agar hasil pelatihan lebih maksimal.

\section{UCAPAN TERIMAKASIH}

Tim pengabdi mengucapkan terimakasih kepada SD Negeri 4 Ngraho yang telah bersedia menjadi mitra dalam kegiatan pengabdian ini. Terimakasih disampaiakn kepada peserta pengabdian yang telah mengikuti kegiatan pelatihan dengan baik sehingga kegiatan dapat berjalan lancar dan bermanfaat. Tim pengabdi 
juga mengucapkan terimakasih kepada Universitas PGRI Yogyakarta yang telah mandanai kegiatan pengabdian ini sehingga kegiatan dapat berjalan dengan lancar.

\section{DAFTAR PUSTAKA}

Adisusilo, Sutarjo, J.R. 2011. Pembelajaran Nilai-Nilai Karakter. Yokyakarta: PT Raja Grafindo Persada.

Khusniati, M. (2012). Pendidikan Karakter Melalui Pembelajaran IPA. Jurnal Pendidikan IPA Indonesia, 1(2).

Kurniawati, W., \& Atmojo, S. E. (2017). Pembelajaran Sains Bermuatan Karakter Ilmiah Dengan Alat Peraga Barang Bekas Dan Asesmen Kinerja. JPI (Jurnal Pendidikan Indonesia), 6(1).

Marjan, J., Arnyana, I. B. P., Si, M., Setiawan, I. G. A. N., \& Si, M. (2014). Pengaruh Pembelajaran Pendekatan Saintifik Terhadap Hasil Belajar Biologi Dan Keterampilan Proses Sains Siswa MA. $\mathrm{Mu}$ allimat NW Pancor Selong Kabupaten Lombok Timur Nusa Tenggara Barat. Jurnal Pendidikan IPA Indonesia, 4(1).

Rahmita, Y. G. (2013). Penerapan pendekatan scientific dalam pembelajaran matematika SMP kelas VII materi bilangan (pecahan). In Prosiding Seminar Nasional Matematika dan Pendidikan Matematika. Jurusan Pendidikan Matematika FMIPA UNY.

Ricahyono, S., \& Arifin, S. (2016). Pelatihan Penyusunan Kegiatan Pembelajaran Paikem Inovatif Berbasis 101 Metode Guna Meningkatkan Kompetensi Pedagogik Guru Mgmp Madrasah Tsanawiah Se-Kabupaten Madiun. Jurnal Terapan Abdimas, 1(1), 43-48.

Setiyaningsih, W., Maimunah, M., \& Siregar, S. N. (2018). Penerapan Pembelajaran Dengan Pendekatan Saintifik Untuk Meningkatkan Hasil Belajar Matematika Siswa Kelas X IPA. 2 SMA Negeri 1 Ujungbatu. Jurnal Online Mahasiswa (JOM) Bidang Keguruan dan Ilmu Pendidikan, 5(1), 1-10.

Suastika, I. K. (2018). Pengembangan Modul Pembelajaran Bilangan Berbasis Tematik Saintifik. Jurnal Inspirasi Pendidikan, 8(1), 24-32.

Zuchdi, D. (2010). Pengembangan Model Pendidikan Karakter Terintegrasi Dalam
Pembelajaran Bidang Studi Di Sekolah Dasar. Cakrawala Pendidikan, 1(3). 